\title{
The Meaning of Life: The Major Philosophical Aspects Hidden Behind a Fundamental Question of Human Existence
}

\author{
By Paul Letsch*
}

\begin{abstract}
The question of the meaning of life is one of the most crucial questions that the human mind is able to produce. The way we respond to it determines the way we design and arrange our life and our culture. So, what exactly do we mean when we talk about the meaning of life? Behind this expression is hiding a set of very diverse philosophical ideas. Analytic philosophy can be the tool to bring these ideas to the surface, clarify their content and study the conceptual compatibility between each other. My reflection starts off with inserting all philosophically relevant historical answers to this question into five categories that serve as references for the whole context. A summarised conceptual and linguistic analysis is then applied to a number of concepts and issues connected to our topic, such as the concept of meaning itself, the moralistic fallacy, the eudemonistic issue etc. This allows to construct a semantic and conceptual network that brings a great deal of clarification and the possibility to find more precise common grounds for discussion about this highly abstract question. The results of this analysis are used to produce, as a personal outlook, the proposal of a new theory concluding that the demand for life's meaning should be placed in a non-religious, non-teleological and intersubjective narrative for normative purposes.
\end{abstract}

\section{Introduction}

This is the best possible candidate for the meaning of life: ${ }^{1}$

The meaning of life is what you can wish to happen in the most favourable case in an unforeseeably faraway future, without having to rely on a God (or something alike), a hereafter or the immateriality of your own person, and the attempt of contributing in the most effective way to its fulfilment.

The paper exposes the reflection leading to this proposal through the clarification of the underlying philosophical concepts of what humanity came up with as answers to the question of the meaning of life. It constitutes one part of the research of a more substantial work in progress for a $\mathrm{PhD}$ dissertation.

A synoptic table of categories, a very brief summary of the analysis of the

"PhD Student, Vrije Universiteit Brussel, and Philosophy Teacher, European School of Brussels III, Belgium.

1. In terms of coherence and consistency according to the argumentation presented in the ongoing writing of my dissertation and the far less elaborated summarised extract of it in this paper. No quote, my own outcome. 
'hidden' philosophical concepts (a compilation of the arguments from the relevant literature mixed with my own personal reflections) and the new proposal, which is then defended on the basis of the previous analysis and which can be seen as the synthetic contribution to this field of research, are included in this paper.

The objective of my research is to achieve a coherent and consistent outcome for a particular linguistic expression (i.e. 'the meaning of life') and for a philosophical field of concepts connected to this expression. Having them spread out in front of us, we can see if they in themselves make any sense, if they are comprehensible and consistent as such, and if it makes sense to combine these concepts in the way that people have done in the past. This approach should ideally produce progress that corresponds to both of the two questions mentioned by Thaddeus Metz:

"When the topic of the meaning of life comes up, people often pose one of two questions: "So, what is the meaning of life?" and "What are you talking about?" The literature can be divided in terms of which question it seeks to answer."2

The focus lies in a non-exclusive way on the Anglo-Saxon analytic philosophy, even though it is far from clear what exact methodology this philosophical school of thought is putting forward. ${ }^{3}$ I also want to emphasise that I exclude serious considerations of ancient Greek philosophy, though knowing perfectly well that the origins of this subject can also be found in it. This should definitely be done by other scholars that have more expertise in this field in order to make this research more complete.

\section{Overview of the Historical Solutions to the Question of the Meaning of Life}

All the historical attempts for solving the demand for life's meaningfulness contain the tendency to express its fundamental metaphysical structure in as few principles as possible. ${ }^{4}$ The categorisation of these attempts is heuristically useful. We can establish two distinct approaches in the form of two pairs of opposites

2. Thaddeus Metz, "The Meaning of Life," in The Stanford Encyclopedia of Philosophy (Fall 2008 Edition), ed. E. N. Zalta, (2007), https://stanford.io/2PeOmPC, introduction.

3. Michael Beaney, "Analysis," in The Stanford Encyclopedia of Philosophy (Summer 2016 Edition), ed. E. N. Zalta, (2003; substantive revision 2014), https://stanford.io/2KLhtck, chapter 9 .

4. Thaddeus Metz, "Recent Works on the Meaning of Life," Ethics 112, no. 4 (July 2002), 783; Thaddeus Metz, "The Meaning of Life," in The Stanford Encyclopedia of Philosophy (Fall 2008 Edition), ed. E. N. Zalta, (2007), https://stanford.io/2PeOmPC, chapter 2. 
(supernaturalism/naturalism $\Leftrightarrow$ objectivism/subjectivism) plus one category for the negation of life's meaningfulness.

This generalised overview is as such already instructive through its emphasis on the key ideas of these conceptual frameworks, but the categories serve above all as referential shortcuts within the analysis of the hidden concepts behind 'the meaning of life'.

The four positive solutions are not strictly distinctive groups because depending on what answer is to be considered, a certain group might become a sub-group of another, which is for instance mostly the case for objectivism and naturalism. This categorisation is largely inspired by Thaddeus Metz, Elmer Klemke and Joshua Seachris.

\begin{tabular}{|c|c|c|}
\hline \multicolumn{2}{|c|}{$\begin{array}{c}\text { Positive solutions } \\
(\rightarrow \text { there is a meaning of life })\end{array}$} & $\begin{array}{c}\text { Negative solutions } \\
(\rightarrow \text { there is no meaning of life })\end{array}$ \\
\hline Supernaturalism ${ }^{5}$ & Naturalism ${ }^{6}$ & Nihilism, pessimism and \\
\hline Objectivism $^{7}$ & Subjectivism $^{8}$ & specific forms of existentialism \\
\hline
\end{tabular}

In his articles, T. Metz divides for instance supernaturalism into a theistic and a non-theistic conception. ${ }^{9}$ The latter having less of an impact in society due to its relatively lower popularity, this differentiation is largely neglected here. ${ }^{10}$ The most representative ideas of the supernaturalist approach in general are at the same time the most relevant ideas of monotheistic religions and the possible theoretical implications they establish onto the world and the whole universe: the idea of God, the idea of an immaterial soul and the idea of an immaterial hereafter.

5. "Supernaturalist theories are views that meaning in life must be constituted by a certain relationship with a spiritual realm." [Thaddeus Metz, "The Meaning of Life," in The Stanford Encyclopedia of Philosophy (Summer 2013 Edition), ed. E. N. Zalta, (2007; substantive revision 2013), https://stanford.io/2P8U59n.]

6. Naturalists are "those who believe that a significant existence can be had in a purely physical world as known by science." [lbid.]

7. "Objective naturalists believe that meaning is constituted (at least in part) by something physical independent of the mind about which we can have correct or incorrect beliefs." [Ibid.] Although, I believe that the supernaturalist theories also belong to the category of objectivism.

8. "According to this view, meaning in life varies from person to person, depending on each one's variable mental states." [Ibid.]

9. Thaddeus Metz, "The Meaning of Life," in The Stanford Encyclopedia of Philosophy (Fall 2008 Edition), ed. E. N. Zalta, (2007), https://stanford.io/2PeOmPC, introduction; Thaddeus Metz, "Recent Works on the Meaning of Life," Ethics 112, no. 4 (July 2002), 783.

10. Conceptually speaking, the discussion about the main ideas of theism covers more or less the discussion about the fundamental ideas of supernaturalist non-theism. 
In principle, Elmer Klemke's categorisation approximately matches with the one from Metz inasmuch as Klemke establishes the pair of opposites 'theistic'/ 'non-theistic' when 'theistic' is understood as supernaturalist and 'non-theistic' as naturalist and only if, as mentioned before for my own approach, the difference between non-theistic supernaturalist theories and theistic supernaturalist ones is not taken into consideration. ${ }^{11}$ Metz does formulate this in a more precise way because it is more consistent to see theism merely as a subidea of supernaturalism. Supernaturalism is the broader concept and as such it is used in this paper. Klemke also adds the semantic examination of the studied expression as an entire independent category. ${ }^{12}$ In contrast to this, Metz pursues the linguistic analysis outside his approach of generalising the historical solutions.

It is interesting to notice that Metz does not draw up a $2 \times 2$ table for the positive solutions (as I am proposing above) but splits up his category of naturalism into objectivism and subjectivism. ${ }^{13}$ This approach can be problematic when a certain form of objectivism is seen as a supernaturalist answer, a circumstance that is mentioned in his own article when claiming that Robert Nozick's naturalist theory is tending towards supernaturalism. ${ }^{14}$ But the approach of Metz can be agreed upon when the only form of objectivism that is being discussed is exclusively a naturalist objectivism. For this reason, it is helpful to explicitly distinguish between 'objective naturalism' and 'subjective naturalism' - like Seachris does ${ }^{15}$ - to avoid misunderstandings.

\title{
Summarised Analysis of the Relevant Underlying Concepts of the Expression 'The Meaning of Life'
}

\author{
The Concept of Meaning
}

The problematic part in the expression 'the meaning of life' is not so much 'life'. 'Life' can be completed with 'my life', 'our life', 'the life of human kind', 'the life of all living creatures', or it can be substituted with 'existence' in general, with 'the totality of the universe' or even with 'being': the expression will still preserve a very similar signification and will still address the same topic. The

11. Elmer D. Klemke and Steven M. Cahn, The Meaning of Life. A Reader, $3^{\text {rd }}$ ed. (New York: Oxford University Press, 2008), 3.

12. Ibid.

13. Thaddeus Metz, "Recent Works on the Meaning of Life," Ethics 112, no. 4 (July 2002), 792. His position stays the same in his more recent articles.

14. Ibid., 799.

15. Joshua Seachris, "Meaning of Life: The Analytic Perspective," in The Internet Encyclopedia of Philosophy (2011), https://bit.ly/2rwZkq0, chapter 3.c. 
more problematic part in our studied expression is the concept of meaning. For the second part in this expression - probably for anthropocentric reasons almost all the studied literature targets our human life, be it individually or collectively.

The concept of meaning in our specific context, as in 'the meaning of life' and not as in 'the meaning of the word bike', has a close connection with the concept of purpose ${ }^{16}$ and with the concept of value ${ }^{17}$. A. J. Ayer, for instance, states that purpose represents in general the matter of an intention that one considers to be desirable, and meaning the attempt to realise the desirable objective. ${ }^{18}$ This is very convincing. But in order to associate purpose with the question of life's meaning, it has to be understood as a freely chosen purpose, as a purpose that we humans determine ourselves if we do not want it to be confounded with the concept of function. ${ }^{19}$ It is important to note that 'purpose' is not used in this article as in 'purpose theory' which can be seen as a certain kind of supernaturalist theory. ${ }^{20}$

'Meaning' in our expression includes necessarily also a direction, as Jean Grondin points out. ${ }^{21}$ The purpose that we want to set up in order to ascribe meaning to our life (or to existence in general) is an objective that lies chronologically ahead of us.

Furthermore, according to Ronald Hepburn, analytic philosophers refuse to assign one single purpose to life when people talk about its meaningfulness. Actually, we always have to deal with multiple purposes that are commonly bundled in the concept of purpose in our context, and all of those purposes are connected to each other in a semantic and conceptual network. ${ }^{22}$ Semantically speaking, could for instance the meaning of life be considered sufficiently covered by the idea of survival? This has to be denied. But it is a necessity to include it.

16. Volker Gerhardt, "Sinn des Lebens" (Meaning of Life), in Historisches Wörterbuch der Philosophie, ed. Joachim Ritter and Karlfried Gründer, vol. 9 (Basel: Schwabe \& Co., 1995), column 815.

17. Ibid.

18. Alfred J. Ayer, "The Claims of Philosophy," in The Meaning of Life. A Reader, ed. Elmer D. Klemke and Steven M. Cahn (New York: Oxford University Press, 2008), 199.

19. Kurt E. M. Baier, The Meaning of Life: Inaugural Lecture delivered at the Canberra University College on 15 October 1957 (Canberra: The Canberra University College, 1957), 20 sqq.

20. Thaddeus Metz, Meaning in Life. An Analytic Study (Oxford: Oxford University Press, 2013), 77-118.

21. Jean Grondin, "Le sens de la vie: une question assez récente, mais pleine de saveur" (The meaning of life: a quite recent question, but full of flavour), Théologiques 9, no. 2 (2001), 12.

22. Ronald W. Hepburn, "Questions about the Meaning of Life," Religious Studies 1, no. 2 (April 1966), 126. 
Hepburn confirms the above by saying that the analysed expression can only be precisely understood when it is connected to a purpose-ascription that targets objectives that we desire. At the same time, Hepburn reveals the link to moral judgements. ${ }^{23}$

"To say that 'making life meaningful' is a matter of 'pursuing valuable, worthwhile ends' is to say that it is an activity that indispensably involves value judgment. The description of cosmic patterns, tendencies or trends does not obviate the need to make autonomous judgments about the worthwhileness or otherwise of following, or promoting or opposing any of these."24

Seachris confirms this viewpoint by saying that most Anglo-Saxon analytic philosophers approach the question with some sort of amalgam that consists of concepts like purpose, value, worthwhileness, meaningfulness, death, futility etc. Besides the moral aspect (right/wrong), also to be considered are aesthetic (good/beautiful), eudemonistic (happiness) claims and the various connections between these aspects..$^{25}$

\section{Normativity}

Meaningfulness gains a lot of transparency when we separate the descriptive Is-dimension from the prescriptive Should-dimension. But the conceptual circumference of one of those two dimensions is not always completely clear: Seachris for instance undertakes a distinction between an explanatory and a normative dimension where 'explanation' means more than just the description of facts. ${ }^{26}$ It means finding out what our different statements mean without necessarily referring to real facts, understanding what we deal with when we look into a matter. ${ }^{27}$ It is very well possible to determine in an explanatory way the meaning of some theory about a cosmic purpose without being able to find describable facts that underlay the existence of this cosmic purpose. On the other hand, it is rather unproblematic to understand 'prescriptive Should-dimension' and 'normative dimension' as the same thing.

Meaning in our sense contains necessarily a normative request and must be distanced from a purely descriptive narrative. We can agree that the occurrence of merely having or owning a purpose (and thus possibly discovering it) does

23. Ronald W. Hepburn, "Questions about the Meaning of Life," Religious Studies 1, no. 2 (April 1966), 127.

24. Ibid.

25. Joshua Seachris, "Meaning of Life: The Analytic Perspective," in The Internet Encyclopedia of Philosophy (2011), https://bit.ly/2rwZkq0, chapter 1.

26. Ibid.

27. Ibid. 
not yet create this normativity, but setting up or creating a purpose does. The latter would exactly be the kind of purpose that we need for having it connected with our 'meaning'. Both 'purpose' and 'meaning' only make sense in this context when we assign them to ourselves and not when it is imposed on us. The act of ascription lies already within normativity if we draw a categorical line to neurological descriptions that could be considered the origin of this act. For instance, the expression 'to be alive' (when nothing jeopardizes this life) is a lot harder to associate with the meaning of life than 'to survive'. This is due to the specificity of 'meaning' within 'the meaning of life'. Trying to survive implies the possible case of not surviving, thus dying. Just merely being alive does conceptually not necessarily imply this because it can be seen as the mere result of a causal chain of something just happening in this universe. The fact that there is an option between survival and no survival gives us the possibility to set up the purpose (which formulated like this is only choosing between one or the other). This is exactly what normativity implies: the possibility for setting up a direction to head to for our actions or thoughts with the necessary existence of one or more alternatives, and thus without being bound by the mere causality of nature, or at least without feeling of being bound by the mere causality of nature. ${ }^{28}$ Another example: it is impossible to see the Christian paradise as meaningful without having a hell (or another alternative) as its counterpart. If paradise would come in any case whatever we do, we could not anymore assign a purpose (in our sense) to it. It might be meaningful for God having created a paradise without a hell for whatever reason that we ignore, but not for us human beings, and this is so because we cannot avoid assigning to 'meaning' its conceptual and semantic specificity.

Finding meaningfulness objectively (whether supernaturalist or naturalist) in an either blindly evolving universe or an intelligence/consciousnessimpregnated (usually immaterial) sphere behind or within this universe fails. The reason for me to exclude pure objectivism from the establishing of a new theoretical proposal is less to be found in the impossibility of explaining the signification of those philosophical theories or in the impossibility of finding hard empirical facts for it, than rather in the impossibility of explaining them without major flaws in putting together their conceptual components in a coherent and consistent way, and especially associating the set of all their components with a correct understanding of 'meaning' (see above): a purpose must be assigned by a subject (be it one individual or a group or the whole society) that consciously sets up a desirable intention, himself and in a noncoercive way, and the attempt of realising this intention creates the meaningfulness of it. In that respect, it does not matter if a cosmic conscious intelligent entity exists or not.

28. This does not necessarily mean that one cannot be a determinist in order to agree with this. 
If we cannot associate meaning with objectivism and we need to associate it with a normative request, are we compelled to adopt subjectivism? It is tempting to assign to any normative request the aspect of subjectivity and to any fact description (and maybe also explanation as such) the aspect of objectivity. But I believe that these associations cannot be upheld rigorously. Every normative request is indeed connected to a decision that, at some point, must be based on our will, based on something that we want. If what we should do or what we should not do is determined by our will, we might want to determine if this will has to be seen as our own individual will independently of others or if we can consider a harmonisation with others, and then we leave the field of pure subjectivity and we enter the one of intersubjectivity. ${ }^{29}$

\section{Rationality, Emotionality and the Moralistic Fallacy}

Are the requests of our will based exclusively on emotions? Is thereby every normative claim irrational? Does unemotional rationality even exist? A part of the early analytic philosophy with Wittgenstein, the Vienna Circle and A. J. Ayer denied any form of rationality towards the 'meaning of life' and all other valuebased and normative requests. ${ }^{30}$ It was often attempted to refute this radical claim, although it is true that we do not really know (yet) how to justify a fundamental normative request.

We have to separate the reasoning about something from the motivation for something to clarify this issue. We may perfectly well accept the scientifically very convincing hypothesis that every will is the product of a neurological state of potentially descriptive and causally determinable facts, nevertheless, it is still right to assume that the foundation of a normative request (that stands for the starting-point of a broader narrative) is solely emotionally motivated: ${ }^{31}$ strictly logically speaking, even if everybody finds it completely 'unreasonable' to wish for our whole species to die out, the last judging instance for finding this 'unreasonable' is the emotion not to want to die out. Logic has nothing to do with not wanting to die out, logic has only something to do with how we possibly will not die out if we wish not to die out. Pure coherent and consistent description of facts does not need any emotions involved for the description process (except for the fact that making this description in the first place is emotionally motivated, otherwise we would not do anything). But normative requests need both

29. Daan Evers and Gerlinde Emma van Smeden, "Meaning in Life: In Defence of the Hybrid View," The Southern Journal of Philosophy 54, no. 3 (Sep. 2016).

30. Winfried Löffler, "Sinn" (Meaning), in Neues Handbuch philosophischer Grundbegriffe, ed. Petra Kolmer and Armin G. Wildfeuer, vol. 3 (Freiburg and München: Karl Alber, 2011), 1995.

31. An emotion that can be scientifically described does not make it less of an emotion. 
emotionality and rationality:

a. The most basic foundation of the normative request, or the most fundamental value to be pursued, needs an emotional motive. ${ }^{32}$

b. This first value ${ }^{33}$ is the starting-point (or maybe in the other direction the final consequence) of a reasoning that constructs a conceptual network of arguments, and the different elements of this network need to be put together by rationality to fulfil the criteria of coherence and consistency.

The biggest problem in this discussion is not that every normative claim (and thus that the most fundamental purpose being established for a theory about the meaning of life) is, at some point, based on an emotion, it is rather the fact that some conceptual approaches for the meaning of life confound the establishment of a purpose based on our will with some objectively real thing that is assumed to exist in the universe or beyond. ${ }^{34}$ This confusion can be called the moralistic fallacy. ${ }^{35}$ The latter allows at least as much arbitrariness as humanwill-based or human-mind-created purposes, probably even more arbitrariness. Supernaturalists, for instance, delegate the will, i.e. what we want, to an external conscious intelligence on a cosmic level. This does not solve anything concerning the meaning of life because the moment we find out that the supernaturalist theory has taken away our responsibility for the purpose-ascription, we realise that we have lost the moral status that we necessarily must possess in order for the meaning of life to make real sense. If the 'meaning' is not 'our meaning' anymore, the concept of meaningfulness for our life loses its specific definition. ${ }^{36}$

32. The following statement, for instance, defends this approach: "But what counts as a worthy object cannot be determined either from a totally neutral and impersonal point of view." [Susan Wolf, "Meaning in Life: Meeting the Challenges," Foundations of Science 21, no. 2 (June 2016), 279.]

33. "first value" not to be confounded with 'intrinsic value'.

34. Karl Popper calls those theories "kritikimmun" and are therefore dangerous. [Winfried Löffler, "Sinn" (Meaning), in Neues Handbuch philosophischer Grundbegriffe, ed. Petra Kolmer and Armin G. Wildfeuer, vol. 3 (Freiburg and München: Karl Alber, 2011), 1998.]

35. Justin D'Arms and E. C. Moore talk about the moralistic fallacy. [Justin D'Arms and Daniel Jacobson, "The Moralistic Fallacy: On the 'Appropriateness' of Emotions," Philosophy and Phenomenological Research 61, no. 1 (July 2000); Edward C. Moore, "The moralistic fallacy," Journal of Philosophy 54, no. 2 (1957).] The term has assumingly been applied toward its present meaning by Bernard B. Davis through the article "The moralistic fallacy," in Nature, vol. 272 (1978). Retrieved from https://go.nature.com/2E7daH4.

36. Ronald W. Hepburn, "Questions about the Meaning of Life," Religious Studies, 1, no. 2 (April 1966), 127: "Religious and metaphysical statements are still statements of fact, and therefore logically cannot in themselves be answers to questions about meaning. Second: if human life is given purpose by virtue of man's fulfilling the task assigned to him by God, it will be 'purpose' in the autonomy-denying, dignity-destroying sense." 
The supernaturalist's 'meaning of life' is merely a 'function of life'.

\section{The Eudemonistic Issue}

The will for something or wanting something is often perceived as directly linked to what can possibly make us happy, whatever this 'being happy' means. Happiness is certainly one of the most popular meaning-ascribing notions that we know of and as such it is one of the hidden aspects of various maxims or theories expressing meaningfulness. The Christian notion of paradise (e.g.) does not make any sense if we could not project a state of perfect (hedonistic) happiness in it. For eudemonistic ethics such as conceived by Aristotle, it is not a hidden aspect but rather the central notion of the narrative. Though, this does not mean that it is always patently linked to the expression of the meaning of life.

Kurt Baier wrote that those who are in search for a meaning of life are evidently looking for a positive meaning. ${ }^{37}$ Hereby the transition to and the visible connection with the context of ethics is confirmed, and the link to the notion of happiness is established. Seachris confirms in his overview article that both ethical, esthetical and eudemonistic requests are contained in the demand for meaning, and that all of them are in certain ways related to each other that have yet to be discovered. ${ }^{38}$

The eudemonistic issue is in some respect more or less present in all the conceptual approaches of the positive solutions, as well for supernaturalists, objective naturalists and subjectivists. Even in the group of the negationists, such as pessimism, the aspect of happiness does play a role too, at least as a denied positive aspect, one that we aspire to, but one that the universe cannot provide us with. ${ }^{39}$ This approach assumes the unquestionable characteristic of the human being of requiring happiness, which is similar (if happiness is situated in or close to a hedonistic narrative) to saying that we aspire to a life devoid of suffering and pain or a life with as little suffering and pain as possible, even if this condition is seen as unreachable (the credo par excellence of Schopenhauer).$^{40}$ It is indeed difficult to imagine that the human being creates willingly a purpose that excludes completely the aspect of happiness.

37. Kurt Baier, Problems of Life $\mathcal{E}$ Death. A Humanist Perspective (Prometheus Lecture Series) (Amherst, NY: Prometheus Books, 1997), 50.

38. Joshua Seachris, "Meaning of Life: The Analytic Perspective," in The Internet Encyclopedia of Philosophy (2011), https://bit.ly/2rwZkq0, chapter 1.

39. Jean Grondin, "Le sens de la vie: une question assez récente, mais pleine de saveur" (The meaning of life: a quite recent question, but full of flavour), Théologiques 9, no. 2 (2001).

40. Arthur Schopenhauer, Die Welt als Wille und Vorstellung (The world as will and representation), complete works and definitive version from Ludger Lütkehaus, $4^{\text {th }}$ ed. (München: Deutscher Taschenbuch Verlag, 2008). 
Of course, talking about happiness should include the study of what happiness consists of, and not only eudemonistic ethics deal with this question. This object of study is not part of this work. But the human being does not always opt for happiness as the most important thing to be pursued in life. Our will can target other worthwhile values: another very different candidate for instance is authenticity. A convincing argument to exclude the eudemonistic aspect as the predominant one from the context of life's meaningfulness is put forward by Robert Nozick's thought experiment called 'experience machine' ${ }^{41} \mathrm{He}$ invites us to imagine living in a virtual machine that feeds our minds with experiences that subjectively produce perfect happiness and a state of absence of complaints, without ignoring though that an 'un-virtual' real life exists outside this machine. Nozick argues that we would not necessarily want to continue to stay in this machine because this kind of life lacks authenticity, this kind of life is a lie. Being aware of this could be enough reason for us to choose to abandon this state of perfect happiness. ${ }^{42}$ Martin Heidegger is also mentioning authenticity as primordial for human existence. ${ }^{43}$ It can be argued that for the meaning of our life, the strongest purpose-giving instance is not happiness but authenticity or maybe even something else that is still to be elaborated. Another question that has to be addressed is if authenticity ascribes happiness to life or vice versa, and how they, if at all, are linked to each other.

Possibly happiness does not constitute the primary value for establishing life's most consistent meaningfulness if we consider imagining a hierarchy of aspects that constitute this meaning. But happiness can at least be considered a bonus candidate that should be included if life's meaning is found to be constructible in multiple alternative ways, which is for instance feasible when we put life's meaningfulness in a subjective or an intersubjective narrative. A possible new theory about the meaning of life should allow some conceptual space for including it.

41. Robert Nozick, Anarchy, State, and Utopia (New York: Basic Books, 1974), 42 sqq.

42. Thaddeus Metz, "The Meaning of Life," in The Stanford Encyclopedia of Philosophy (Fall 2008 Edition), ed. E. N. Zalta, (2007), https://stanford.io/2PeOmPC, chapter 1. But the inverse argument can also be defended, which is done, for instance, in a scene in the movie Matrix (1999; directed by the Wachowski brothers) where Cypher offers to the agents to betray Neo in order to be put back into the Matrix with a privileged life.

43. Charles Guignon on Heidegger: "To live authentically, then, is to [...] direct oneself towards the fulfilment of one's own life story with clarity, integrity and steadfastness, and $[\ldots]$ to take responsibility for what one's own life is adding up to, resolutely holding to one's own chosen life-defining commitments by carrying forwards [...] what one has been in one's undertakings." [Charles Guignon, "Martin Heidegger: Being and Time," in Central Works of Philosophy, vol. 4, ed. John Shand (Montréal: McGillQueen's University Press, 2006), 101.] 


\section{Meaninglessness and Absurdity}

The two notions of meaninglessness and absurdity can be used synonymously, and the authors who do so connote both notions with something negative and irrational. Or they can be conceptually and semantically separated if this is useful for clarification purposes. 'Meaninglessness' can be distinguished from 'absurdity' as being the difference of for instance 'the universe or some divine entity does not provide us and life in general with some kind of purpose' and 'I don't feel (subjectively) any purpose in my life' (as in a state of depression). The difference lies between externality (outside the mental sphere) and internality (inside the mental sphere). Approximatively, the first notion would be a conceptual component of an objectivist narrative, be it supernaturalist or naturalist, and the second notion a conceptual component of a subjectivist narrative. Joel Feinberg for instance talks about the difference between "absurdity in life" and "absurdity of life". ${ }^{44}$ The first would correspond to the above mentioned 'absurdity', the second to 'meaninglessness'. Thomas Nagel distinguishes also the "in our life"-perspective from the "outside our life"-perspective, whereas both perspectives combined are producing absurdity in his opinion. ${ }^{45}$ Thaddeus Metz gives preference to the formulation also used in this article when he says that "Nagel distinguishes between the meaninglessness of a life and its absurdity". ${ }^{46}$

This differentiation is helpful to extract the hidden objectivist approach from the narratives defending a life of absurdity. The considered authors are inferring their absurdity from a meaningless universe in the sense described before, ${ }^{47}$ and there is no logical necessity to do so when meaning is to be produced by a conscious future-projecting mind that establishes it. On this point for instance, Camus and Sartre disagree with each other, although Sartre also bases his reflection on a partly contingent universe. ${ }^{48}$ But he does not deduce the absurdity of human existence from this contingency. On the other hand, a subjectivist may have a much harder job to believe in the inevitability of absurdity because his choice of replying to the demand for meaning depends entirely on himself and

44. Joel Feinberg, "Absurd Self-Fulfillment," in The Meaning of Life. A Reader, ed. Elmer D. Klemke and Steven M. Cahn (New York: Oxford University Press, 2008), 155.

45. Thomas Nagel, "The Absurd," in The Meaning of Life. A Reader, ed. Elmer D. Klemke and Steven M. Cahn (New York: Oxford University Press, 2008), 145.

46. Thaddeus Metz, "Recent Works on the Meaning of Life," Ethics 112, no. 4 (July 2002), 811 (footnote).

47. Albert Camus, Le mythe de Sisyphe. Essai sur l'absurde (The Myth of Sisyphus: An Essay on the Absurd) (Collection folio essais, no. 11) (Paris: Gallimard, 1985); Jacques Monod, Le hasard et la nécessité. Essai sur la philosophie naturelle de la biologie moderne (Chance and Necessity: An Essay on the Natural Philosophy of Modern Biology) (Paris: Éditions du Seuil, 1970).

48. Jean-Paul Sartre, L'existentialisme est un humanisme (Existentialism is a Humanism) (Collection Pensées) (Paris: Nagel, 1946). 
his liberty of constructing it.

Again, the blindly and unconsciously evolving universe not having by itself a meaning is as such evidently only problematic for objectivists. Either they wish for a phenomenon to contain something that is by its true nature merely a product of our mind (which can thus be called moralistic fallacy) and which - not finding it - will turn them into defenders of absurdity without necessarily being consistent enough to permanently stay in this state of resignation, or they recur to the hypothesis of a cosmic intelligence and wish, as supernaturalist objectivists, to delegate the establishing of meaning to this cosmic intelligence that has that (very human) faculty of planning into the future and setting up an intuitively felt positive goal towards which we should head to. This undertaking can be considered an anthropomorphism and is therefore as such a dubious thought process for our context.

Jean Grondin underlines the circumstance that the negationists are only able to discover absurdity because they are hiding their very strong wish for life to have a fulfilling meaning without discovering it and thus without being able to avoid a feeling of resignation. ${ }^{49}$ The cosmic irrationality assigned by Camus and Monod upon existence can be solved by simply giving up objectivism. ${ }^{50}$

Probably the most famous portrayal of absurdity has been done by Albert Camus and his Myth of Sisyphus. ${ }^{51}$ Richard Taylor and Joel Feinberg studied this myth to elaborate a further understanding of the approach of denying meaningfulness to life. .52

\section{The Perspective}

For Thomas Nagel, the concept of absurdity has its origin in our mental faculty to adopt different perspectives for looking at ourselves and our own life..$^{53}$ The two extremes of the spectrum of possible perspectives, the view from within

49. Jean Grondin, "Le sens de la vie: une question assez récente, mais pleine de saveur" (The meaning of life: a quite recent question, but full of flavour), Théologiques 9 , no. 2 (2001), 7 .

50. Albert Camus, Le mythe de Sisyphe. Essai sur l'absurde (The Myth of Sisyphus: An Essay on the Absurd) (Collection folio essais, no. 11) (Paris: Gallimard, 1985); Jacques Monod, Le hasard et la nécessité. Essai sur la philosophie naturelle de la biologie moderne (Chance and Necessity: An Essay on the Natural Philosophy of Modern Biology) (Paris: Éditions du Seuil, 1970).

51. Albert Camus, Le mythe de Sisyphe. Essai sur l'absurde (The Myth of Sisyphus: An Essay on the Absurd) (Collection folio essais, no. 11) (Paris: Gallimard, 1985).

52. Richard Taylor, "The Meaning of Life," in The Meaning of Life. A Reader, ed. Elmer D. Klemke and Steven M. Cahn (New York: Oxford University Press, 2008), 134 sqq.; Joel Feinberg, "Absurd Self-Fulfillment," in ibid., 154 sqq.

53. Thomas Nagel, "The Absurd," in The Meaning of Life. A Reader, ed. Elmer D. Klemke and Steven M. Cahn (New York: Oxford University Press, 2008). 
our own mind and the view from an outside point in the universe, collide with each other. ${ }^{54}$ The subjective perspective is the one we usually adopt in everyday life. Nevertheless, the human being has also the capacity to zoom out of this inner mental world to a spatial and temporal endlessly faraway point and moment in the universe (called sub specie aeternitatis). ${ }^{55}$ Sub specie aeternitatis, we can look back at us in a completely objectivised way, in a "detached amazement", 56 from where we start to question ourselves, our actions, our habits, our possessions and our values. Without being able to ignore that we still are that person, that tiny element that we look at, the feeling of contingency overwhelms us. For Nagel, the discrepancy of these extreme viewpoints produce absurdity in a philosophical sense. ${ }^{57}$ The more external our perspective is, the more we have to increase the frame in which we try to establish meaningfulness. ${ }^{58}$ Embracing God as frame does not necessarily solve the problem either, ${ }^{59}$ he being supposed to exist beyond all imaginable frame. In his later work The View from Nowhere from 1986 although, Nagel tries to overcome his own dilemma by setting up an ethical approach:

"far enough outside your own life to reduce the importance of the difference between yourself and other people, yet not so far outside that all human values vanish in a nihilistic blackout". ${ }^{60}$

I see in this approach of irreconcilable perspectives a similarity to the Myth of Sisyphus. ${ }^{61}$ Camus also speaks of a conflict between two different tendencies of our mind: on one hand, the tendency to reduce everything down to general rational principles, on the other hand, the tendency to see the universe as something irrational and contingent. Both Nagel and Camus see philosophical reflections as the source of inevitable absurdity and its immediate effect on the psychic constitution of the human being. Camus fights this absurdity off with a particular state of mind that includes defiance and rebelliousness. ${ }^{62}$

I think that this type of discrepancy between perspectives or between conflictual mental tendencies is merely another approach of the very old
54. Ibid., 145.
55. Ibid., 146.
56. Ibid.
57. Ibid.
58. Ibid., 147.

59. Ibid.; Volker Gerhardt, "Sinn des Lebens" (Meaning of Life), in Historisches Wörterbuch der Philosophie, ed. Joachim Ritter and Karlfried Gründer, vol. 9 (Basel: Schwabe \& Co., 1995), column 821.

60. Ibid.

61. Albert Camus, Le mythe de Sisyphe. Essai sur l'absurde (The Myth of Sisyphus: An Essay on the Absurd) (Collection folio essais, no. 11) (Paris: Gallimard, 1985).

62. Ibid., 77-78, 167-168. 
amazement about our self-awareness or self-consciousness, only substituted by a new model of explanation. Our mental capacities produce reflections that make us see humanity and ourselves as ridiculously unimportant in the overwhelmingly vastness of the universe. But assessing meaningfulness of our life by measuring an inappropriate kind of importance that depends on our smallness within time or space is not necessarily consistent, because both are distinct categories. This does not mean though that the aspect of time does not play any role in the necessary components of meaningfulness. ${ }^{63}$

\section{The Standard}

Iddo Landau shows in a convincing way that the assessment of meaningfulness depends on the evaluation standard that we assign to this meaningfulness, ${ }^{64}$ rather than on the fearful and exaggerated proportion we are supposed to adopt within a certain spatio-temporal scale.

By the definition of standard itself, the one for meaningfulness is evidently set up by ourselves and can thus - depending on who sets it up and how he does it - vary strongly. It is quite easily imaginable to demand a very moderate standard for the cosmic perspective, even sub specie aeternitatis in an objective and impersonal way, ${ }^{65}$ since one cannot be necessarily deduced from the other. The assumption of smallness and very low impact upon the universe sub specie aeternitatis does not necessarily imply that life has to be seen as meaningless. ${ }^{66}$ Pessimists establish unreachable and god-like standards for life, without really justifying these standards. They set up a threshold for meaningfulness around aspects like absence of suffering, permanent or quasi-permanent presence of happiness, immortality etc. Though, establishing these exaggerated standards can be regarded as completely arbitrary and not standing up to critical questioning. ${ }^{67}$ It equals what could be called the imaginary fantasy of the theists without being able to recur to immaterial phenomena and thus failing meaningfulness as such in their sense. Kurt Baier claims already in 1957 that also Christianity contains unjustified exaggerated evaluation standards of life. ${ }^{68}$ This

63. See below under the chapter "The Infinite Regress".

64. Iddo Landau, "The Meaning of Life Sub Specie Aeternitatis," Australasian Journal of Philosophy 89, no. 4 (December 2011); Iddo Landau, "Standards, Perspectives, and the Meaning of Life: A Reply to Seachris," Ethical Theory and Moral Practice 17, no. 3 (June 2014).

65. Iddo Landau, "The Meaning of Life Sub Specie Aeternitatis," Australasian Journal of Philosophy 89, no. 4 (December 2011), 727.

66. Ibid., 727, 733.

67. Paul Edwards, "Life, meaning and value of," in The Encyclopedia of Philosophy, vol. 4 (New York: The Macmillan Company \& The Free Press, 1967), 473.

68. Kurt Baier, The Meaning of Life: Inaugural Lecture delivered at the Canberra University College on 15 October 1957 (Canberra: The Canberra University College, 1957), 27. 
is also the reason why it is so difficult to refute pessimism in a consistent way when we discuss with them. We realise that our arguments will not convince them precisely because of the relativity of the standards which might have been set up by people from a very different theoretical, psychological or cultural background. Spinoza for instance argues the complete opposite, that a completely miserable life has to be preferred over the inexistence of life, and logically speaking there is nothing wrong with this claim either. ${ }^{69}$

\section{Value, Intrinsic Value and the Worthwhileness}

Is the evaluation standard completely arbitrary? Can we just make it up out of nothing if we are not allowed to connect it with a spatio-temporal perspective? Assigning a standard to something, as well as assigning a purpose to something, must necessarily depend on the values that we cherish. Though, this does not yet prevent arbitrariness because now it is the value that depends on us, our feelings and thoughts. Both 'meaningfulness' on one side and things like 'value' and 'honour' on the other side are not to be discovered in nature itself. ${ }^{70}$ The latter is a belief that the value-objectivists defend, for instance by stating that the human mind is also part of nature (which I completely agree with), but unless one does not reduce everything to a descriptive ethical approach - the human mind included - this position lacks the justification of having a cause for discussion in the first place. ${ }^{71}$ 'Having meaning' and 'having value' share the same sort of characteristic as established ideas in order to present adequate significations for our context. Though constructed by our mind, these ideas seem to present a high degree of persistence. It is for instance possible to radically modify all of a sudden one's ideology (which could also be a religious faith) without neither losing life's meaningfulness nor one's basic values for life. ${ }^{72}$ Values and their corresponding meaningfulness might be of a more fundamental nature than political or religious ideologies, even if both dimensions are possibly connected to each other in some way.

Humans seem to know intuitively what matters to them for their life, i.e. what is valuable. Prominent candidates for values are creativity, performance,

69. Paul Edwards, "Life, meaning and value of," in The Encyclopedia of Philosophy, vol. 4 (New York: The Macmillan Company \& The Free Press, 1967), 475.

70. Ronald W. Hepburn, Christianity and Paradox (Critical Studies in TwentiethCentury Theology) (London: C. A. Watts, 1958), 152.

71. Joseph Runzo, "Life, meaning and value of [addendum]," in The Encyclopedia of Philosophy, ed. Donald M. Borchert, $2^{\text {nd }}$ ed., vol. 5 (Detroit: Thomson Gale, 2006), 358; Susan Wolf, "Meaning in Life: Meeting the Challenges," Foundations of Science 21, no. 2 (June 2016), 233.

72. Joseph Runzo, "Life, meaning and value of [addendum]," in The Encyclopedia of Philosophy, ed. Donald M. Borchert, $2^{\text {nd }}$ ed., vol. 5 (Detroit: Thomson Gale, 2006), 358. 
substantial contribution for diminishing suffering of ourselves and others, promotion of happiness or well-being, human relationships etc. ${ }^{73} \mathrm{~K}$. Baier adds other notions to this: discoveries, inventions, admiration and respect. ${ }^{74}$ The concept of liberty that is put forward by Bertrand Russell is also noteworthy, a concept that he defines as an approval of one's own ideals. ${ }^{75}$

In the reviewed literature, the notions 'value', 'intrinsic value' and 'worthwhileness' are recurrently being discussed. 'Value' and 'worthwhileness' seem to be often treated synonymously. It is more relevant to figure out if 'value' must be understood in the sense of being intrinsic or in the sense of being dependent on and being deduced from other human and social phenomena and/or other values and thus if values should be seen for our purposes as being elements of an interconnected network of concepts.

Based on statements from K. Baier, R. Hepburn suggests furthermore that meaningfulness includes both hedonistic and non-hedonistic objectives. ${ }^{76}$ If meaningfulness must include more than just hedonistic values (the most immediately felt ones and thus very good candidates for being intrinsic), than the values that have to be considered here could be ones that emerge from a set of human and social phenomena or other values that are interdependent. In this case, one value gets its justification by deducing it from others. Even so-called intrinsic values are seen as being the top of a hierarchy of secondary or intermediate values, as it is for instance done by Aristotle for his happiness. Thus, a determining connection within a justification chain of arguments does exist for 'intrinsic' values, making them less intrinsic than they are supposed to be.

The same reflection - needing a coherent network of arguments and basing concepts on the principle of interdependency - constitutes also the foundation for overcoming arbitrariness, and not merely by claiming that they cannot possibly be products of our mind. A final describable justification for something does not have to exist. The only thing that matters is that the network holds together coherently and consistently and the fact that it can potentially be constructed endlessly. Implementing values in this network also means that we have to refuse to see values as intrinsic at least for our context.

73. Robert Audi, "Intrinsic Value and Meaningful Life," Philosophical Papers 34, no. 3 (Nov. 2005), 333-334.

74. Kurt Baier, The Meaning of Life: Inaugural Lecture delivered at the Canberra University College on 15 October 1957 (Canberra: The Canberra University College, 1957), 27.

75. Bertrand Russell, "A Free Man's Worship," in The Meaning of Life. A Reader, ed. Elmer D. Klemke and Steven M. Cahn (New York: Oxford University Press, 2008), 58-60.

76. Ronald W. Hepburn, "Questions about the Meaning of Life," Religious Studies 1, no. 2 (April 1966), 128. 


\section{The Infinite Regress}

Building up an endlessly vast network of arguments and concepts faces the critic of not being able to avoid the infinite regress. Every justification, every argument must be supported by yet other ones and so on. But at this point, it can be asked if the infinite regress as never-ending argumentation chain has to be considered an enemy to reason or philosophical reflection. I plead to see the validity of an argumentation in the consistent connections of its semantic and conceptual network that is being constructed, not in the circumstance of not having precise boundaries of that network.

It is possibly just a matter of modesty to overcome the idea of necessarily having those boundaries, those starting- or end-points that seem to give peace of mind. Knowing that we can never have a first reason per se does not mean that we have to resign from the motivation of creating more and more knowledge, also philosophical knowledge. This is the same approach as the one they have in hard sciences. And this approach is also the most beneficial aspect of contemporary analytic philosophy in regard to the question of the meaning of life.

For seeing philosophical knowledge as constructing a strong conceptual and semantic network, I also disagree with the following kind of claim:

"First, life does not consist of a sequence of activities each of which has as its purpose some later member of the sequence. Chains of justification come repeatedly to an end within life, and whether the process as a whole can be justified has no bearing on the finality of these end-points." 77

The opposite might be true: life does consist of a sequence of activities (especially, for instance, for a successfully developed life), and existence as a whole is a sequence of lives. Already in everyday life, the planning of family matters consists of not seeing things as isolated activities. And the more we overcome seeing things as isolated phenomena, the better we can face the difficulties for the years to come and for the generations after us. If this was not true, then we have to see everything as secluded systems which only makes sense when we keep in mind that we have them artificially set up for specific purposes (like in scientific experiments) without really believing that the universe contains them as such. It is irrelevant if we ever find a final end-point, but it is very relevant that we extend our knowledge continuously without necessarily ever having to arrive somewhere final, which we could call asymptotic approach. Though, dogmatically thinking to find an objectively existing final end-

77. Thomas Nagel, "The Absurd," in The Meaning of Life. A Reader, ed. Elmer D. Klemke and Steven M. Cahn (New York: Oxford University Press, 2008), 144. 
point and establishing a hypothetical and temporary final end-point for normative reasons is a very different thing.

\section{Death and Immortality}

Already Kohelet complained about the fact that the beautiful things in life come to an end with death. ${ }^{78}$ This is one of the arguments recurrently put forward by the theists pleading to overcome this circumstance through believing in a life after death.

The fear of death as an inevitable end to individual life and the wish for immortality play a dominant role in the discussion of the demand for life's meaningfulness. Antony Flew's studies about Tolstoy's Confession give us confirmation. ${ }^{79}$ And all it precisely proves is that we are not able to completely endorse the intrinsicality of values or the detachability of human activities for this context. As meaning-ascribing beings, we establish projections far into time, and preventing us from pursuing those projected situations scares us. It is precisely death that prevents this future projection. But only a specific notion of death, even though a very popular one, embraces this particular signification: death of the individual person. Because the difference between death of an individual person and death of humanity or even death of biological life as such is an essential one in this context. Antony Flew states the following:

"The contention is that our lives can have meaning only on the assumptions of the existence of God and of human immortality."80

Twenty-one years before writing this, he had already given an explanation why this approach lacks validity:

"It is at least no less rational to hold that it is precisely our mortality which makes what we do, or fail to do, so overwhelmingly important. And there is not the slightest warrant for suggesting that this alternative and opposite reaction is possible only for those who are lacking in imagination." ${ }^{81}$

78. Kurt Baier, The Meaning of Life: Inaugural Lecture delivered at the Canberra University College on 15 October 1957 (Canberra: The Canberra University College, 1957), 24.

79. Antony Flew, "Tolstoi and the meaning of life," Ethics 73, no. 2 (Jan. 1963); Lew Tolstoj, Meine Beichte (My Confession), trans. Alexis Markow (Berlin: Insel Verlag, 2010).

80. Antony Flew, God, Freedom, and Immortality. A Critical Analysis (Amherst, NY: Prometheus Books, 1984), 155.

81. Antony Flew, "Tolstoi and the meaning of life," Ethics 73, no. 2 (Jan. 1963), 113. 
Elmer Klemke agrees with Flew: the absence of life's meaningfulness through seeing life coming to an end has as much and as little validity as the opposite claim. ${ }^{82}$

I share with Flew and Klemke the opinion that an individual life does not decrease its meaningfulness by having to end, but for another reason, a reason that can best be labelled with the expression "the stream of life", an idea asserted by Bertrand Russell. ${ }^{83}$ Russell sees the individual life's meaning in being inserted in a stream of multiple individual lives, of attached generations that follow each other, and precisely not in the idea of seeing lives as secluded entities: like billiard balls that are never being nudged and thus are never colliding with other balls, which would be a precondition for not being able to play a game. Again, seeing any kind of phenomena as secluded entities does not match with empirical reality and lacking foresight of what could be targeted does not help to establish normativity. Seeing any kind of phenomena as secluded entities does e.g. also not match with Heidegger's disagreement of the "assumption that Being [as such] is defined by enduring presence [...] [which] continues to be taken as self-evident throughout the history of mainstream Western thought", ${ }^{84}$ especially in the case of human life as such. Charles Guignon writes:

"[Heidegger's] claim is that instead of thinking of humans as individuals, persons, selves or subjects, or even as collectives, we should think of human existence as the emergence of an open "space of meaning"," 85

Meaningfulness in the sense of a being pulled towards an ascribed purpose can only emerge when life is inserted in bigger systems without necessarily adopting an inconsistent supernaturalist connotation. The system in which we insert meaningfulness can very well be an earthly one, one that is happening in this physically describable world or universe. ${ }^{86}$ This view is consistent with inserting meaningfulness into a conceptually interconnected network. But does an open-end network-based justification for values and meaningfulness not collide with the assumption that humanity has also to end sometime, even if only in a very far future? Russell does for instance predict an end for humanity from cosmic incidences, and it feels contradictory to accept the stream of life and at the same time being forced to restrict one's projection into the future, whatever

82. Elmer D. Klemke and Steven M. Cahn, The Meaning of Life. A Reader, $3^{\text {rd }}$ ed. (New York: Oxford University Press, 2008), 4. 175.

83. Bertrand Russell, The Conquest of Happiness (Abingdon: Routledge Classics, 2006),

84. Charles Guignon, "Martin Heidegger: Being and Time," in Central Works of Philosophy, vol. 4, ed. John Shand (Montréal: McGill-Queen's University Press, 2006), 94.

85. Ibid., 98.

86. Bertrand Russell, The Conquest of Happiness (Abingdon: Routledge Classics, 2006), 175. 
timespans we are dealing with. Therefor Russell shifts the emphasis of his notion of meaningfulness to intrinsic values. But he is consistent in doing so, because if he is begging for life's meaningfulness and if he is convinced that our life might end someday, then there is probably no alternative. My question to him would then be: why coming up with the concept of the stream of life in the first place? Intrinsic values can rather arbitrarily be placed on anything that the human being cherishes, like a happy moment, a tasty meal or a single scientific discovery. As discussed before, meaninglessness or absurdity is indeed inevitable if the stream of life has to stop without being deviated to an immaterial sphere or to a possible intrinsicality of values.

But there are three things to be considered here:

1) Do we know for sure about these cosmic incidences that bring the end to humanity? No, we do not. The big cosmic theories in physics have changed quite often in the last decades, there is no certainty about those general cosmic future predictions. In addition to this, mathematical chaos theory proves that an accurate future prediction for highly complex systems is impossible. We simply cannot predict things of that scale: a newly discovered parameter can change everything in our predictions. And this is quite fortunate since we claimed that the infinite regress has to be considered as auxiliary and not as adversary. John Kekes had made a very interesting reflection on this: "[...] through placing my happiness in something durable and distant, in which some progress might always be making, while it could never be exhausted by complete attainment." ${ }^{\prime 87}$ If we substitute in this quote "my happiness" with 'the meaningfulness of my life', then it would express exactly what has been said above.

2) Does requesting a projection with a potentially temporal open-end contradict with the denial of Nagel's discrepancy of perspectives? No, because when we assume an open-end-projection, we are not talking about spatial smallness (which leads to insignificance according to Nagel). Neither are we talking about situating us in an endless timeframe and measuring our proportion to this infinity, but we consider a never-ending time in the sense that we are not allowing ourselves to arbitrarily determine a precise moment for the purpose of ascribing normativity to our life. We are actually not talking about significance at all. If we wish so, significance can just emerge from standards that we are ascribing to the world.

3) Does death of the individual person mean the end of this future projection that we are requesting? No, if we are modest enough to set up more accurate standards, then we must admit that everything we do leaves

87. John Kekes, "The Meaning of Life," in The Meaning of Life. A Reader, ed. Elmer D. Klemke and Steven M. Cahn (New York: Oxford University Press, 2008), 241. 
traces behind, and even the apparently most negligible traces have in some respect an impact on that stream of life which could be all we need for ascribing meaningfulness to our life and which could be all we need for motivating us to develop or increase a possibly positive impact on the universe. A simple example would be the attempt to give a good education to one's children. But, of course, it can also be something completely different.

\section{Teleology}

Since the teleological approach requires a finality in a cosmic sense, its defenders consequently assert that this finality has to be discovered as an external goal toward which everything is being pulled without necessarily having this goal considered as a divine plan. Within the frame of this approach, this is not contradictory as such, but we have clarified further above what 'meaning' has to mean. We remember that 'purpose' and 'meaning' must be established by ourselves in a non-coercive way for it to be accurately called that way in our context. A. J. Ayer adds that this is true even if we are more or less coincidently able to comply with this cosmic purpose imposed on us. ${ }^{88}$ Furthermore, a teleological explanation does in this respect not differ from a causal explanation, whether the reason for something's existence is being determined by an incidence in the past or in the future: in both cases, we deal with a mere description, at least in principle, and as such it must be refuted for life's meaningfulness. ${ }^{89}$

\section{A Proposal for a New Theory about the Meaning of Life}

Considering the previous analysis, my proposal for a new theory about the meaning of life ${ }^{90}$ can be understood and defended with the following points:

1. The proposal consists of two parts (separation point at "and"). The first part of the proposal contains the purpose-ascription, the second one the more specific normative request that calls for action. ${ }^{11}$ Both parts contain an ethical normative dimension, on the one hand the aspect of expressing our will, on the other hand the aspect that one should act effectively in

88. Alfred J. Ayer, "The Claims of Philosophy," in The Meaning of Life. A Reader, ed.

Elmer D. Klemke and Steven M. Cahn (New York: Oxford University Press, 2008), 199.

89. Ibid.

90. See beginning of article (Introduction).

91. I am not excluding that the first part also represents a normative claim, it is maybe just less visible, hidden behind the purpose-ascription (which is as such, as we have seen, also normative). 
accordance to this will. ${ }^{22}$ These parts are not to be separated if compatibility with the analysis should be maintained.

2. The proposal is not a knowledge of external facts. The only thing that could possibly be discovered as facts within this issue is the neurological process of the active mind expressing its will, but it is useful, and probably even necessary, to separate the category of normative statements from the category of statements of facts in order to get results for this field of research. I believe that these categories have to be 'artificially' separated in order to avoid a stagnant loop of reflection since the studying subjects and the studied objects happen to be the same thing in this context: us human beings.

3. Even if our supposedly free and independent emotion-based will ${ }^{93}$ is to be considered the source of the purpose-ascription, it seems to be clear that the proposal hardly justifies complete arbitrary decisions about the construction of a wishful ideal future projection. The imagination and the projection of an ideal future must comply, as the starting-point (or as a final consequence), with a vast conceptually network-based justification that does not allow incompatibility with both the external and internal human reality (for instance that we are emotional beings in need for love, affection, shelter, food etc.) and the reality on the whole (for instance that a healthy diversified nature is a precondition for our survival and maybe for life itself). And even if some individuals can possibly wish for our species to die out, it does not seem to be the case for life as such, us human beings for the vast majority included.

4. A temporal restriction of the projection that assigns purpose has to be put aside (which we do with "in an unforeseeably faraway future"94) if we want to do justice to the infinite regress, avoiding thus at some point falling into the trap of question-begging. R. Hepburn defends this approach:

a. "[...] there seems nothing logically impossible in human beings setting themselves infinitely distant goals of aspiration; even although they might prove unrealizable in full, and even although there existed no perfect being who either realized them in his own

92. Cf. Charles Guignon on Heidegger: "To live authentically, then, is to [...] direct oneself towards the fulfilment of one's own life story with clarity, integrity and steadfastness, and [...] to take responsibility for what one's own life is adding up to, resolutely holding to one's own chosen life-defining commitments by carrying forwards [...] what one has been in one's undertakings." [Charles Guignon, "Martin Heidegger: Being and Time," in Central Works of Philosophy, vol. 4, ed. John Shand (Montréal: McGillQueen's University Press, 2006), 101.]

93. The belief in the actual existence of a free will in a metaphysical sense is not required. The freedom of choice in this context can be merely seen as the absence of political, social and physical coercion.

94. See beginning of article (Introduction). 
person or who set those goals before humanity. To be able to pursue perfection does not entail that perfection exists; any more than the procession of natural numbers demands that there exists some last and greatest number of all." ${ }^{95}$

b. "The atheistic-romantic conception of man as ceaselessly striving for an ultimately unattainable, but infinitely desirable goal, is not [...] a self-demolishing one." 96

5. The projection of an ideal situation in an unforeseeably faraway future allows the proposal to be seen in a sufficiently general and universal way in order to avoid a normative request that would be too detailed for not taking into account the connections and the complexity of a very broad (maybe the broadest) context which is being addressed by the expression 'the meaning of life'. But this does not exclude the possibility for normative detailed specificities to be validated by this proposal.

6. This proposal does indeed put forward the idea that the meaning of life has to be seen as a projection of ideals that the human being chooses with the awareness of him having an impact on the future, as small or futile this might seem in the vastness of the universe surrounding him, though without being of complete irrelevance. An impact, as small as it might be, is still an impact, and for that reason has a raison d'être.

7. The proposal has to be seen as the starting-point of the above-mentioned network-based justification approach. This implies that every element (theory, thought, maxim etc.) in this network has to be connected to the others in a coherent and consistent way. Within this network, rational argumentation is required to assure this.

8. Why "without having to rely on a God (or something alike), a hereafter or the immateriality of your own person"97? The belief in a supernaturalist world, a God or immaterial phenomena in general does not allow a contradictory free reasoning in our context. The supernaturalist hypothesis is furthermore unnecessary when establishing a very convincing meaning of life. ${ }^{98}$

9. The part "the immateriality of your own person" contains a thought element that has been addressed among others by Kant with his Categorical

95. Ronald W. Hepburn, Christianity and Paradox (Critical Studies in TwentiethCentury Theology) (London: C. A. Watts, 1958), 179.

96. Ibid., 180.

97. See beginning of article (Introduction).

98. The following article is supporting my argument: Jason Megill and Daniel Linford, "God, the meaning of life, and a new argument for atheism," International Journal for Philosophy of Religion 79, no. 1 (February 2016).

99. See beginning of article (Introduction). 
Imperative and by John Rawls. ${ }^{100}$ The idea is that, in order to establish moral and normative content, one has to neglect the importance and the relevance of his own person alone and of his own interests alone. Furthermore, with 'immateriality' I want to avoid clinging to one's own individual person in a hypothetical life after death.

10. "What you can wish": 101 the combination of 'to be able to' and 'to wish' might in some respect make an allusion to Kant's Categorical Imperative formulation "whereby you can at the same time will", 102 but a correct interpretation of Kant's deontology is not intended here, even though there might be a similar idea behind it for this part of the proposal. For my means, I combine the ideas of 'being able to' and 'wishing for' to express that the purpose-ascription should not be completely arbitrary and completely subjective. The freely and independently expressed wish of one human being or all the human beings as a whole should be 'harmonised', not by a political or social authority nor an impulsive instinct or egoistic emotion, but by a reflective and well-considering mind within an intersubjective approach. ${ }^{103}$

\section{Conclusion and Possible Ideas to Be Pursued}

The theoretical proposal with its defending arguments is the result of an analysis of the philosophical aspects that are gathered within the main historical approaches in philosophy that address directly or indirectly the question of the meaning of life. ${ }^{104}$ I think that the analytic approach allows much clarification on this topic. It brings forward the intertwined ramifications that this topic contains. The proposed theory has predominantly the achievement of setting some conceptual limits by excluding ideas which are useless and even destructive if the expression has to make any real sense. Another positive outcome of this

100. Immanuel Kant, Grounding for the Metaphysics of Morals, $3^{\text {rd }}$ ed., trans. James W. Ellington (London: Hackett, 1993); John Rawls, A Theory of Justice (Cambridge, MA: Harvard University Press, 1971).

101. See beginning of article (Introduction).

102. "Act only according to that maxim whereby you can at the same time will that it should become a universal law without contradiction." Immanuel Kant [1785], Grounding for the Metaphysics of Morals, $3^{\text {rd }}$ ed., trans. James W. Ellington (London: Hackett, 1993), 30.

103. Thaddeus Metz is referring to a promising theory of Stephen Darwall. [Thaddeus Metz, "Recent Works on the Meaning of Life," Ethics 112, no. 4 (July 2002), 795; Thaddeus Metz, "The Meaning of Life," in The Stanford Encyclopedia of Philosophy (Fall 2008 Edition), ed. E. N. Zalta, (2007), https://stanford.io/2PeOmPC, chapter 3.]

104. The work (in German) on which the PhD dissertation (that this article has partly summarised) is based on and that contains this is freely available at: https://bit.ly/2Ed0 WwJ. 
conceptual and linguistic investigation is the fact that the refusal of both the supernaturalist and the strictly naturalist approach does neither necessarily lead to a depressively felt absence of meaningfulness in life nor to a superficial and merely directly felt subjectivist theory that is just not taking enough into account the broader implications of all the philosophical aspects involved. This positive outcome was not being begged for, but it appeared as such through the investigation. A self-projecting ascription of purposes should be considered both as a motivation and as real-existing mind-products that can be partially objectivised by an intersubjective approach.

I think that one of the biggest misguidances in matters of argumentation is what can be labelled 'moralistic fallacy'. The building up of the proposed theory is predominantly an attempt to avoid this trap. Throughout the history of philosophy, emotions and logic were tried to be kept apart to allow progress in thinking, and I believe that this matter is still a very big issue. Emotions are as such a very important part of human reality and it has to be considered in the investigation of the wishes and needs of the human being, but the reflection on this investigation itself, the meta-level, should not be misled by emotional fallacies if the fundamental principles of coherence and consistency are to be implemented in the thought process.

In the near future, neurosciences might produce some very interesting outcomes about the neurological process of establishing purpose and meaningfulness inside the human mind, and philosophical conclusions will probably have to be modified and improved upon these outcomes.

\section{Acknowledgements}

I would like to express sincere thanks to the VUB University, to my $\mathrm{PhD}$ supervisor Marc Van den Bossche, to my friends Aikaterini Lefka, Ian Brown and Paul Sharry, and to my wife Barbora Rutová for supporting my research.

\section{Bibliography}

Audi, Robert. "Intrinsic Value and Meaningful Life." Philosophical Papers 34, no. 3 (Nov. 2005): 331-355.

Ayer, Alfred J. "The Claims of Philosophy." In The Meaning of Life. A Reader, edited by Elmer D. Klemke and Steven M. Cahn. New York: Oxford University Press, 2008.

Baier, Kurt E. M. The Meaning of Life. Inaugural Lecture delivered at the Canberra University College on 15 October 1957. Canberra: The Canberra University College, 1957.

. Problems of Life \& Death. A Humanist Perspective. Prometheus Lecture Series. Amherst, NY: Prometheus Books, 1997. 
Beaney, Michael. "Analysis." In The Stanford Encyclopedia of Philosophy, edited by Edward N. Zalta. Summer 2016 Edition. First published 7 April 2003, substantive revision 19 March 2014. Retrieved from https://stanford.io/2KLhtck.

Camus, Albert. Le mythe de Sisyphe. Essai sur l'absurde (The myth of Sisyphus. An essay on the absurd). (Collection folio essais n $\left.{ }^{\circ} 11\right)$. Paris: Gallimard, 1985.

D’Arms, Justin, and Daniel Jacobson. "The Moralistic Fallacy: On the 'Appropriateness' of Emotions." Philosophy and Phenomenological Research 61, no. 1 (July 2000): 65-90.

Edwards, Paul. "Life, meaning and value of." In The Encyclopedia of Philosophy, edited by Paul Edwards. Vol. 4. New York: The Macmillan Company \& The Free Press, 1967.

Evers, Daan, and Gerlinde Emma van Smeden. "Meaning in Life: In Defense of the Hybrid View." The Southern Journal of Philosophy 54, no. 3 (Sep. 2016): 355-371.

Feinberg, Joel. "Absurd Self-Fulfillment." In The Meaning of Life. A Reader, edited by Elmer D. Klemke and Steven M. Cahn. New York: Oxford University Press, 2008.

Flew, Antony. God, Freedom, and Immortality. A Critical Analysis. Amherst, NY: Prometheus Books, 1984.

"Tolstoi and the meaning of life." Ethics 73, no. 2 (Jan. 1963): 110-118.

Gerhardt, Volker. "Sinn des Lebens" (Meaning of Life). In Historisches Wörterbuch der Philosophie, edited by Joachim Ritter and Karlfried Gründer. Vol. 9. Basel: Schwabe \& Co., 1995.

Grondin, Jean. "Le sens de la vie : une question assez récente, mais pleine de saveur" (The meaning of life: a quite recent question, but full of flavor). Théologiques 9, no. 2 (2001): 7-15.

Guignon, Charles. "Martin Heidegger: Being and Time." In Central Works of Philosophy, edited by John Shand. Vol. 4. Montréal: McGill-Queen's University Press, 2006.

Hepburn, Ronald W. Christianity and Paradox. (Critical Studies in Twentieth-Century Theology). London: C. A. Watts, 1958.

"Questions about the Meaning of Life." Religious Studies 1, no. 2 (April 1966): 125-140.

Kant, Immanuel [1785]. Grounding for the Metaphysics of Morals, translated by James W. Ellington. 3rd ed. London: Hackett, 1993.

Kekes, John. "The Meaning of Life." In The Meaning of Life. A Reader, edited by Elmer D. Klemke and Steven M. Cahn. New York: Oxford University Press, 2008.

Klemke, Elmer D., and Steven M. Cahn. The Meaning of Life. A Reader. 3rd ed. New York: Oxford University Press, 2008.

Landau, Iddo. "Standards, Perspectives, and the Meaning of Life: A Reply to Seachris." Ethical Theory and Moral Practice 17, no. 3 (June 2014): 457-468.

"The Meaning of Life Sub Specie Aeternitatis." Australasian Journal of Philosophy 89, no. 4 (Dec. 2011): 727-734.

Löffler, Winfried. "Sinn" (Meaning). In Neues Handbuch philosophischer Grundbegriffe, edited by Petra Kolmer and Armin G. Wildfeuer. Vol. 3. Freiburg and München: Karl Alber, 2011.

Megill, Jason, and Daniel Linford. "God, the meaning of life, and a new argument for atheism." International Journal for Philosophy of Religion 79, no. 1 (Feb. 2016): 31-47.

Metz, Thaddeus. "The Meaning of Life." In The Stanford Encyclopedia of Philosophy, edited by Edward N. Zalta. Summer 2013 Edition. First published 15 May 2007, substantive revision 3 June 2013. Retrieved from https://stanford.io/2P8U59n. 
Vol. 6, No. $3 \quad$ Letsch: The Meaning of Life: The Major Philosophical Aspects...

. "The Meaning of Life." In The Stanford Encyclopedia of Philosophy, edited by Edward N. Zalta. Fall 2008 Edition. Published 15 May 2007. Retrieved from https://stanford.io/ 2PeOmPC.

. "Recent Works on the Meaning of Life." Ethics 112, no. 4 (July 2002): 781-814.

. Meaning in Life. An Analytic Study. Oxford: Oxford University Press, 2013.

Monod, Jacques. Le hasard et la nécessité. Essai sur la philosophie naturelle de la biologie moderne (Chance and necessity. An essay on the natural philosophy of modern biology). Paris: Éditions du Seuil, 1970.

Moore, Edward C. "The Moralistic Fallacy." Journal of Philosophy 54, no. 2 (1957): 29-42.

Nagel, Thomas. "The Absurd." In The Meaning of Life. A Reader, edited by Elmer D. Klemke and Steven M. Cahn. New York: Oxford University Press, 2008.

The View from Nowhere. New York: Oxford University Press, 1986.

Nozick, Robert. Anarchy, State, and Utopia. New York: Basic Books, 1974.

Rawls, John. A Theory of Justice. Cambridge, MA: Harvard University Press, 1971.

Runzo, Joseph. "Life, meaning and value of [addendum]." In The Encyclopedia of Philosophy, edited by Donald M. Borchert. 2nd ed. Vol. 5. Detroit: Thomson Gale, 2006.

Russell, Bertrand. "A Free Man's Worship." In The Meaning of Life. A Reader, edited by Elmer D. Klemke and Steven M. Cahn. New York: Oxford University Press, 2008. . The Conquest of Happiness. Abingdon: Routledge Classics, 2006.

Sartre, Jean-Paul. L'existentialisme est un humanisme (Existentialism is a humanism). (Collection Pensées). Paris: Nagel, 1946.

Schopenhauer, Arthur. Die Welt als Wille und Vorstellung (The World as Will and Representation). Complete works and definitive version from Ludger Lütkehaus. 4th ed. München: Deutscher Taschenbuch Verlag, 2008.

Seachris, Joshua. "Meaning of Life: The Analytic Perspective." In The Internet Encyclopedia of Philosophy. Published 2011. Retrieved 27 Sep. 2014 from https://bit.ly/2rwZkq0.

Taylor, Richard. "The Meaning of Life." In The Meaning of Life. A Reader, edited by Elmer D. Klemke and Steven M. Cahn. New York: Oxford University Press, 2008.

Tolstoj, Lew. Meine Beichte (A Confession). Translated by Alexis Markow. Berlin: Insel Verlag, 2010.

Wolf, Susan. "Meaning in Life: Meeting the Challenges." Foundations of Science 21, no. 2 (June 2016): 279-282. 